\title{
Collaborative Governance as a Management Innovation in Local Decentralization
}

\author{
Titik Djumiarti ${ }^{1 * *}$ \\ ${ }^{1}$ Public Administration Departement, Universitas Diponegoro Jl. Prof. H. Soedarto, S.H. Tembalang, Semarang, Indonesia
}

\begin{abstract}
Abstact. The objective of this research was to manage innovations in local government. Collaborative governance based on innovation governance in local decentralization. Case study used research was about Environmental Management on community based settlement in Kendal Regency. This research explores with qualitative approach to explain the governance collaboration within domain analysis method. The domain is seventh of collaborative governance dimension, such as: 1) power dimension, 2) commitment dimension, 3) cultural internalization, 4) strategy dimension, 5) goal dimension, 6) visibility and awareness dimension, 7) problem solving dimension. Due to seventh dimensions is linked to ten principles of Good Governance, such as we also identity a series of factors that are critical within the collaborative process itself. This factors include face to face dialogue, trust building and the development of commitment and share undertanding. The result of this research are Researchers see that PLPBK program in Kendal is able to be the best practice of decentralization that will be beneficial and has a high quality for the local government and the society that lives in it. This Article concludes with discutions of the implications of our contingency model for practitioners and for future resarch on colaborative Governance.
\end{abstract}

Keywords: Decentralization; Governance Innovation; Collaborative Governance; Good Governance.

\section{Introduction}

Decentralization concept is needed to linkage the perspective on a political historic in a State. The most successful experiments in decentralization have mobilized the support and commitment of political, governmental, and civic leaders to sustain governance reformation.

Those changes worth recognizing as innovation should be...new to the organization, be large enough, general enough and durable enough to appreciably affect the operations or character of the organization. ${ }^{1}$

Collaboration setting is created, shared, transferred and adopted by the following best practices for the goal achievement, and also governance'sinnovationsneed to be considered. Innovation has been influencing the political arrangement in local governance. We need to understand much more about the organizational processes of innovation development through 'top- down' policy development, through 'bottom-up' innovation emerging from the activities of managers and staff in organizations, and through 'lateral' innovation from good practice adoption and adaption[1]. Changing is carried by innovation and improvement. Improvement is emerged after the innovation, but changing is showed through the impact of innovation.

The change of governance concept from decentralization brings a new concept of participation. Based on decentralization, an innovation will change the management which later create a collaborative governance. Collaborative dimension can be seen through: 1) Partnership relation and to build the communities, consistency development, and commitment between actors; 2) Collaboration as a tool for negation process and compromise preparation; 3) As a central point to regulation drafting and monitoring and coordination; 4) The following collaboration turn out the power source and authority; 5) The actors commitment is visible; 6) Collaboration can build the internal motivation of the people who join the program.

\footnotetext{
* Corresponding author: titi.artik@yahoo.co.id
} 
Decentralization is one of the effective environmental management strategies in the regions within the framework of regional autonomy by involving the participation of the community in environmental protection and management. However, in addition to natural resources contributing greatly to development, on the other hand sustainability of its availability is often overlooked and so are the rules that should be adhered to as the basis for managing a business and / or activities to support development from the economic sector that is less noticed, so there is a tendency to decline carrying capacity of the environment and depletion of available natural resources as well as deterioration in the quality of the environment [6].

Development funds, though, can serve as depositories of donor and government money and as mechanisms for allocating these resources in ways that are disaggregated to suit the very often smallscale projects and activities that need support in order to improve local livelihoods and stimulate demands for a decentralized form of governance. Decentralization in Indonesia, based on Law No. $32 / 2004$ about local government, shared resposibility, transfer authority from central government to local government. The aim of decentralization is to increase performance effeciency and effectiveness. In democratic countries, framework of decentralization, one of strategic policy to concencus development on central government and local relationship.

Case study in this journal is about Environment Management on Community Base (Penataan Lingkungan Permukiman Berbasis Komunitas (PLPBK)). Decentralization is applicable in this case study, which is to increase poor communities to encourage their participation on participation planning. PLPBK has 1 pilot project, the rest 3 locations of PLPBK program are done afterwards. The 4 sites are located in Kendal Regency.

The aim of this journal is to explain about collaboration as one of innovations in decentralization concept on case study Environment Management by Community Base (Penataan Lingkungan Berbasis Komunitas (PLPBK) at Kendal Regency, Central Java, Indonesia).

\section{Methodology}

This research is using the explorative research type with qualitative approach to explain the governance collaboration by observing: 1) The commitment of the actors involved, 2) Expand the institution capacity to collaborate in PLPBK program, 3) The strategy used in building partnership and collaboration, 4) The instrument used by the actors involved, 5)The factors that obstruct the expansion of PLPBK program especially in the governance collaboration.
Collaborative definition is means joint working or working in conjunction with others. It implies actors-individuals, groups or organizationscooperating in some endeavour. Collaboration involve several distinct dimensions. First, involve cooperation to build commonality, improve consistency and align activities between actors. Second, collaboration can be the process of negotiation, involving a preparedness to compromise and make trade-offs. Third, involve oversight roles, checking and central coordination. Fourth, can involve power and coercion, the ability to force outcomes. Fifth, can involve future commitment and intentions, prospektifbehaviour, planning or preparation to align activitys, Finally can involve enggagement, development of internal motivations and personal commitment project, decisions, organizational goals or strategic objectives[2].

Riant Nugroho stated that there are six external factors that support the alternation; they are work performance, technology, economical surprises, competition, the newest trend and the world's political situation. Generally, there are some reasons why an organization needs some alternations[3]. They are: (1) Alteranation (2) Limitness; and (3) Gap.

Goverment have to pay attention for the internal factorsin organization, such as: (1) Vision and organization strategic vision (2) Human resources (3) Organization structure (4) Leadership (5) Organization culture (6) Organization process[4]. External factors strengthen, encourage and influence the working performance in an organization. The external component, such as: (1) Policy and Government, (2) Technology, (3) Social Value, (4) Customer or user needs, (5) Competition.

Collaborative Governance as a reason for Change Management Organization; The change of management process trigger eight-stage proces: (1) Establing asense of urgency- increase urgency, (2) Forming a powerfull guiding coalition-build the guiding team, (3) Create a vision-get the vision right, (4) Communicate-communicate for buy-in, (5) Empower people-empower action. (6)Winningcreated short-term wins, (7) Consolidate-don't let up, (8) Reinforce-make change stick[5].

Kotter refers and concerns about the common thread in successful change management, such as: The same understanding between the actors on public policy is necessary, Acceptance by the actors, Participation by the actor that supposed to be 'joined up'. The main focus in collaboration is the definition about partnership or working with each other, which involve an individual actor, organization or other group as an analysis of the involvement actor in the program. Based on collaboration that have been described, the data obtained can be seen in Table 1 . 
Table 1.

Contrasing Context, Purpose, Choices, And Motivations Of Collaboration

\begin{tabular}{|l|l|l|}
\hline Context \& purpose & \multicolumn{2}{|l|}{ Choices or motivational possibilities } \\
\hline Power dimension & Coercive and forced collaboration & $\begin{array}{l}\text { Persuasive and voluntary involvement in } \\
\text { collaboration }\end{array}$ \\
\hline Commitment level & Meaningful and substantive collaboration & Meaningless and cosmetic collaboration \\
\hline Cultural internalisation & $\begin{array}{l}\text { Philosophical commitment to } \\
\text { collaboration-development of } \\
\text { collaborative cultures }\end{array}$ & $\begin{array}{l}\text { Collaboration as a tool, an available } \\
\text { instrument-no real commitment to } \\
\text { collaboration as a modus operandi }\end{array}$ \\
\hline Strategic dimension & $\begin{array}{l}\text { Collaboration for positive and beneficial } \\
\text { reasons }\end{array}$ & $\begin{array}{l}\text { Collaboration for negative and/or } \\
\text { preventive strategies }\end{array}$ \\
\hline Means-ends dimension & $\begin{array}{l}\text { Collaboration as a means and process; } \\
\text { stages, due process }\end{array}$ & $\begin{array}{l}\text { Collaboration as an end and outcome; } \\
\text { shared results, outcome orientation }\end{array}$ \\
\hline Goal dimension & $\begin{array}{l}\text { Shared objectives; mutual intentions, } \\
\text { consensual strategies and outcomes }\end{array}$ & $\begin{array}{l}\text { Competing objectives; different reasons } \\
\text { for participating in collaboration }\end{array}$ \\
\hline $\begin{array}{l}\text { Visibility and awareness } \\
\text { dimension }\end{array}$ & $\begin{array}{l}\text { Overt and public forms of collaboration; } \\
\text { awareness of collaboration is high }\end{array}$ & $\begin{array}{l}\text { Covert and behind-the-scenes } \\
\text { collaboration; unawareness of } \\
\text { collaboration }\end{array}$ \\
\hline Problem applicability & $\begin{array}{l}\text { Collaboration on simple problems; simple } \\
\text { objectives and responsibilities }\end{array}$ & $\begin{array}{l}\text { Collaboration on 'wicked' problems; } \\
\text { defying description and solutions }\end{array}$ \\
\hline
\end{tabular}

\section{Discussion}

By having decentralization, it is hoped that there will be some better changes in every region.

Through region autonomy, every area is expected to compete in producing some new innovations. Innovations lead to alternation so in this way alternation management is very needed to be done to prevent an organization or a district from stagnation. In Management collaboration, every organization need a away to record an appraise its innnovative performance.

Government collaboration which is a form of innovation in this research, can be seen through some of the dimensions that lead to good governance principles. Dimension of power that exist in the government collaboration, synergy or lead to the principle of efficiency/effectiveness and the rueach and every region le of law.

Commitments Dimension, which are used in the government's collaboration with the relevant stakeholders, need to work together with the elements of openness and accountability. This was shown in research in the PLPBK program that shows the commitment of the actors who are in to lead to one goal.

Internalization of cultural dimensions, which are used in the program achievements need to work together with the elements of justice (equity). This is necessary because Indonesia is rich in tradition and culture. The element of justice can be seen in Kendal district.The religiousMoslem culture that developed in that district shows a very deep gender differentiation. Thus the success can be achieved in a program.

Strategic dimension is used for this analysis of Strenght, Weakness, Opportunity and Threat (SWOT) and the result is Collaborative for positive and beneficial reason. The fact describes the successful collaboration factors. Weakness by facts on the field describes the lack of human resources and budget for community empowerment. In Kendal Regency, the distinction orientation between the actors in local position (Tim Inti PLPBK) Sectoral ego coming up by the strong Moslem religion value. Opportunity, private partnership has been initiated by Kendal Regent, Widya Kandi Susanti to develop PLPBK Program Threat, community empowerment has modified trash into something useful. The raw materials become an obstacle. People in the location PLPBK program are not used to sort the trash. Purpose dimension, PLPBK program is using top down (shared objectives), and bottom up (different reason for participating in collaboration).

Accountability strengthening on PLPBK program involves the private sector. Leading sector for PLPBK program in Kendal Regency is Dinas Cipta Karya dan Tata Ruang. Visibility and Awareness dimension leads to Overt and Public Form of Collaboration. Voluntary participation by the society is an act that shows changing that they want into their life. Problem solving dimension on PLPBK program leads to collaboration on wicked problem. The appropriate solving of the society's problem should be based on their geographical characteristic, society characteristic, and social culture, etc.

\section{Conclusion}

The success of this program is not merely because of the government's role in managing the society, and on the other hands, the society is only a small part of the local government in Kendal. Based on the research, PLPBK is the best practice to encourage all the regions not to focus only on their weaknesses. This happened because PLPBK focus mainly on the poverty prevention through social, economical and environmental continued development. In this program, the collaboration can be seen between the stakeholders for a successful PLPBK.

Recommendation for this program by looking at the seven dimension used to value the success of colaboration in the best practice PLPBK, the writer concluded that collaboration can be used as one of the new management systems to create decentralization in certain region from zero to hero. Increase the youth empowerment to improve the society participation program, due to young people it would argumented the perspective and more creativity to program development.

\section{References and Notes}

1. J. Hartley, Innovation in Governance and Public Services: Past and Present, Public Money and Management January (2005). 
2. J. Wanna, Collaborative Government : meanings, dimensions, drivers and outcome, Academy of Management Journal, 40, 5 (2008).

3. R. Nugroho, Change Manajemen Untuk Birokrasi, Jakarta, PT Elex Media Komputindo (2013).

4. A. Joko Purwanto et al, Materi Pokok Inovasi dan Perubahan Organisasi, Jakarta, Universitas Terbuka (2010).

5. J. P. Kotter, Leading Change, Boston, Harvard Bussines School Press (1996).

6. Supriadi, Hukum Lingkungan DiIndonesia Suatu Pengantar, Jakarta: Sinar Grafika, (2010).

\footnotetext{
* Corresponding author: titi.artik@yahoo.co.id
} 